\title{
IDENTIFYING THE CONGRUENCE AMONG THE PRESUMED, COMMUNICATED AND PERCEIVED BRAND POSITIONING STRATEGIES OF INDIAN AUTOMOBILE BRANDS
}

\author{
Saloni Pawan Diwan* \& B. S. Bodla \\ salonipdiwan@gmail.com \\ University School of Management, \\ Kurukshetra University, \\ Kurukshetra-136 119, India
}

\begin{abstract}
The incidence of congruence among presumed, communicated and perceived positioning strategies off our Indian car brands (WagonR, Santro, Spark and Figo) is examined. The triangulation research methodology (pilot survey, secondary data and content analysis) is applied to examine the three populations (expert views, advertising strategies and consumer perceptions) considered in the study. The results reveal the popularity of two positioning strategies i.e. "Visual Artistic" and "Basic Features" in case of three car brands whereas Figo stands on the positioning of "Cost and Finance." Regarding the congruence among experts'presumed strategies and the communication tactics employed by selected car brands, it is observed that all the communicated strategies are not presumed and thus ambiguities prevail in the process. This paper also calls the corporate attention to the fact that even positioning strategies perceived by the customers are not presumed by experts and hence there is need to re-assess the brand positioning strategies to curtail these ambiguities. However, the positioning activities highlighted in communications are successfully recognized by the target customers to some extent. The paper concludes with the discussion on managerial implications and limitations.
\end{abstract}

Keywords - automobile industry, car brands, congruence, perceived strategies, positioning activities 


\section{Introduction and background of the Study}

The development of positioning strategy is of utmost importance in marketing strategy formulation as it makes a product clear, distinctive and desirable in customers' minds and leverage the strategic advantage in the market. Arnott (1992) describes positioning as 'the deliberate, proactive, iterative process of defining, measuring, modifying, and monitoring consumer perceptions of a marketable object... 'Literature reveals the significant contribution made by numerous authors (Lawler - Wilson \& Fenwick, 1978; Aaker \& Shansby, 1982; Park et al., 1986; Ries \& Trout, 1986; Kotler, 1988; Dovel, 1990; Hooley \& Saunders, 1993; Blankson \& Kalafatis, 2004; Janiszewska \& Insch, 2012; Chowdhury \& Marketer, 2013; Kachersky \& Carnevale, 2015; Shams, 2015; Jun \& Park, 2017; Park et al., 2017; Wang, 2017; Fayvishenko, 2018) in this direction. They attempt to highlight the impact of positioning in modern marketing management. The essence of positioning is not what you do to the product. It is about what you do to the mind of the customer. It is not to create different but to change or manipulate what you already have (Ries and Trout, 1986).While formulating the positioning strategies, the marketers decide the appropriate position of their brands within the category and relative to the competition. Once the positioning strategy is decided, it is communicated through various media. Positioning and advertising are grilled together to create value and gain the competitive advantage as is also evidenced from the writings of Ries and Trout (1981); Aaker and Shansby (1982); Batra et al.(1996); Alden et al. (1999); Fill (1999); and Blanks on (2004). According to these authors, 'advertisements today, have an explicit objective i.e. the establishment, reinforcement or modification of the positioning of an offering in consumer's mind. Whether a brand would succeed or fail in the marketplace depends to a great extent on its positioning in the eyes of customers. Therefore, a task of evaluating the effectiveness of this positioning exercise is of paramount significance. It is also supported by Seggev (1982); Rossiter and Percy (1997); Alden et.al. (1999); Blankson (2004); and Blank son et al. (2014; 2017) who further indicate that since the ultimate objective of products'/ services'/ brands' (offerings') advertising emanate from positioning activities, the main concern of marketers and researchers must be the assessment of the degree to which desired positioning has been accomplished. Accordingly, an attempt is made to evaluate the offering's positions in market place in case of four popular Indian car brands. This evaluation is useful for managers in knowing the degree to which the desired position has been accomplished. 
The rationale of this study is that in Indian scenario, the increasing rate of per capita income, changing social needs of people, technological advancements and innovations, availability of car loans and affordable rates of interests and the deductions offered to customers by the retailers have paved the way for tough competition in passenger car segment. Today, attracting and retaining a customer is just like winning a battle and thus positioning of car brands and measurement of its effectiveness becomes an important concern of research. Further, the determination of congruence in positioning activities is important to know the effectiveness of companies' efforts (Rossiter \& Percy, 1997; Diwan \& Bodla, 2014-15; Lee et al., 2018) Without evaluating the programs, the gaps and ambiguities could not be estimated and corrected. So, in the light of this, the present article attempts to investigate the positioning activities of four Indian car brands (WagonR, Santro, Spark and Figo). These competitive brands are chosen purposively as these belong to the similar price range and chase the similar target segment.

\section{Research Objectives}

The present study aims to achieve the following objectives:

1. To determine the customers' perceptions of brand positioning strategies of selected car brands (perceived positioning);

2. To study the brand positioning strategies employed in the marketing communications of car brands (communicated positioning);

3. To understand the brand positioning strategies presumed to be followed by experts of car brands (presumed positioning); and

4. To test the congruence among perceived, communicated and presumed positioning strategies of selected car brands.

\section{Research Design}

To accomplish the above objectives, a comprehensive research design was formulated which is discussed as under:

As a first step, to know the customers' perceptions of brand positioning strategies of selected car brands, a questionnaire was designed. The newly developed positioning typology (Diwan \& Bodla, 2011) was incorporated in the questionnaire (Appendix 1) and respondents were asked to respond on 7-point Likert scale where 1 stood for very irrelevant and 7 for very relevant. Further, a sample of 400 respondents was taken with convenience and snowball sampling techniques. These respondents were the 
customers who own the selected car brands. The justification of the selection of this sample unit is in line with Fletcher and Bowers (1991) who stated that in positioning research, the important requirement is to conduct the research among people who already use the product or who are likely to use it. In all, 400 respondents were sent questionnaires, out of which 209 filled questionnaires ( 52 percent response rate) were received back after second reminder to non- respondents. Further, these filled questionnaires were checked for completeness and incomplete 16 questionnaires were discarded. In all, 193complete questionnaires were considered yielding an effective 48 percent response rate. The customers' responses were assigned the codes and data was analyzed with ANOVA.

The research design for second objective (communicated positioning strategies) constitutes the collection of advertisements of selected car brands. For this purpose, 145 advertisements were collected in all from newspapers (102), pamphlets (20), magazines (4) and T.V. (19) concerning recent years.

Further, to study the presumed positioning strategies by experts of selected car brands, the secondary data was collected from web-sites of the respective companies and articles in car magazines such as Overdrive, Top Gear, and Autocar. This data consisted of the information about experts' presumptions regarding their respective car brands. Finally, the congruence or link among perceived, communicated and presumed positioning strategies was examined.

\section{Measurements}

As mentioned above, this paper adopts a newly developed positioning typology to measure the employment of the positioning strategies of selected car brands (Appendix 1). The justification of adopting this typology is that it is designed for automobile industry and it is consumer generated. One another strong factor is the criticisms leveled against existing positioning typologies on the basis of their difficult operationalization (Crawford, 1985, Easingwood and Mahajan, 1989) and authors of the selected typology claim that it is easy to operationalize. This adopted positioning typology has eight dimensions which are collectively measured as summated scales of 52 items. Each step in this typology relates to consumers' perceptions and is practically grounded. The decision of selecting this typology is also supported by Park et. al (1986) and Hooley and Saunders (1993) who say that if positioning strategies are based on examination of consumers' perceptions then these are successful strategies and could last longer. Moreover, marketers may face difficulties in applying 
positioning strategies, if these are not consumer-generated (Piercy, 1991; de Chernatony, 1994; Piercy, 2005).

The data of target group's perceptions of brand positioning strategies in case of each car brand is analyzed with analysis of variance (ANOVA) at a 5\% level of significance throughout the study. The applied null hypothesis is that the responses follow a uniform pattern (Childers et al., 1980; Hornik, 1982; Hawes et al., 1987; Jobber, 1989; Blankson \& Kalafatis, 2007). In case, where the null hypothesis is rejected, the data is analyzed with two multiple comparison tests i.e. Scheffe as well as Tukey (Malhotra \& Dash, 2009). However, the results from both tests are same with no variation but following the good practices of literature, Scheffe's multiple comparison test is adopted in the present study (Blank son, 2004).

Similarly, to know the communicated positioning strategies, the data of advertisements from each media is analyzed with content analysis. This technique is used for summarizing any form of content by counting its various aspects and interprets meanings from the contents of the text data. In this study, each ad copy is analyzed in the light of above discussed positioning typology. Frequency system is adopted as a coding procedure. Code 1 is given in the case where there was occurrence of a specific strategy out of the designed typology as suggested by FrankfortNachmias \& Nachmias (1996). As highlighted in literature (Martenson, 1987; Stern and Resnik, 1991), each ad copy is coded using the scale items of all the eight positioning strategies designed for the study. If any of the scale items out of the construct is present, the presence of the particular positioning strategy is considered. This is also clarified from the fundamental principle of summated scales. So, multiple counting of the single strategy is not present. The data collected with content analysis is subjected to ANOVA, which examines the overall variance in means for two or more populations. A 5\% level of significance is adopted in the whole study. Separate ANOVA test is carried out for each media and the results of positioning strategies are presented in respective tables. In cases, where the null hypothesis is rejected i.e. significant difference between positioning strategies in different ads are detected, data is analyzed with the help of Scheffe's multiple comparison test, which is used to make pair-wise comparisons of all treatment means (Malhotra \& Dash, 2009). The good reason for using this technique in case of communications is found in Cochran (1950), Hsu and Feldt (1969) and Blank son and Kalafatis (2004, 2007). 


\section{Results and Discussion}

The data of brand positioning strategies of each car brand is analyzed with ANOVA and Scheffe's multiple comparison test. " $x$ " indicates the strategies in the subset associated with the highest values. A 5\% level of significance is adopted throughout the study. In this section, only the summarized results are presented. The complete ANOVA results are presented in Appendix 2.

\section{Positioning Strategies: WagonR}

It is world's first tall-boy van styled passenger car of Maruti. As far as presumed positioning strategies of this car are concerned, Table I reveals two strategies presumed to be pursued by experts i.e. "Visual Artistic" and "Basic Features". It is also supported by one official saying "The product gels with people lifestyle, reflecting their confidence and multifaceted personality. By sheer excellence of engineering it enables them to be whatever they choose to be - and that is what makes the buyers interested"(W1).

In communications, company is trying to employ multiple positioning strategies as is evidenced from the presence of five strategies (Table I) in pamphlets. T.V. advertisements besides highlighting "Basic Features" and "Contemporary Features", also work on "Visual Artistic" part and try to build brand personality. Newspapers project "Promotional Campaigns". It is also supported by a caption for one of the print advertisements which goes like "It defied convention and changed the way people looked at a car. It is simply unmatched in performance and comfort. Test-drive one and you'll never settle for anything ordinary again". It is also supported by other like "There are some people who tower over the others. They follow their hearts, create their own rules and lead much fuller lives. The WagonR is for such people. The result of inspired engineering, it defied convention and changed the way people looked at a car..." (W1).

In target group's perceptions, there is presence of five positioning strategies (Table I) out of which "Visual Artistic" and "Basic Features" are presumed as well as communicated. This car is from the house of Maruti and brand image of this company is very good as it is edging the competition on the basis of quality products in medium price range and strong dealer network and services. Customers have strong bent of mind in favor of Maruti and hence also perceive other strategies like "Brand Image", "Dealer Network and Services" and "Cost and Finance", however these strategies are not communicated by the company. 


\section{Positioning Strategies: Santro}

Table II indicates the positioning strategies of Santro, an entry level compact car by Hyundai. The presumed strategy of Santro is only "Visual Artistic". This is because Santro has been repositioned from 'family car' to 'sunshine car' (a smart car for young people). This repositioning is to give this car a younger look and to keep the excitement about the Santro alive in the tough competition. It is also substantiated by one expert by saying... "the average age of a first - time car buyer in India has declined from around 30-35 three years ago to 25-30, primarily because of changing lifestyles and cheap and easily available finance. And the company wants to catch the young" (W2).

As the communicated strategies point out, with the presumed strategy, differentiation is tried to make in messages and as a result overall five strategies are communicated. As far as the target group's perceptions are concerned, there is evidence of multiple strategies but significant matching among presumed, communicated and perceived strategies lies only in case of "Visual Artistic". In case of the rest of the strategies, the ad campaigns and customers perceptions are somewhat similar.

\section{Positioning Strategies: Spark}

Experts express that Spark being a compact car is positioned on style and features. As one expert states ... "its design was meant to appeal to young car buyers in urban markets, with an emphasis on fuel economy and value" (W3). Most ads of this car are found in newspapers and television. A lot of "Promotional Campaigns" take place to make this car penetrate in the market. The newspaper ads not only focus upon its "Basic Features" but low price is also promoted. The perceived strategy of "Cost and Finance" is found in line with communicated but not with presumed practice. The congruence can be seen in Table III in two positioning strategies of Spark namely "Visual Artistic" and "Basic Features".

\section{Positioning Strategies: Figo}

The positioning strategies of this small hatchback car are highlighted in Table IV. Experts followed the strong price positioning for this small atom bomb. Ford, in its portfolio, has the entire sedan cars at higher price range for India but as $70 \%$ segment of Indian market is of hatchback cars, so, Ford planned to introduce Figo in this segment at strong price positioning. The price positioning is used to survive the competition with other major players of this segment like Maruti, Hyundai and Tata. 
The communicated strategies of Figo carry multiple messages. Price positioning is communicated but additionally other copy points are also touched in advertisements. With price, "Visual Artistic", "Basic Features" and "Brand Image" are conveyed to the target segment. "Security Measures" are flavored only in pamphlets as these carry the detailed specifications and have limited reach. Target group perceptions reveal that the communicated strategies are also perceived by the target customers. People cherish by having a stunning car at price of just 3.5 lakhs embedded with all the features and that also from the house of Ford. But as far as congruence among the three practices in this study is concerned, it is found only in case of "Cost and Finance".

\section{Congruence Among Positioning Activities}

The results of the congruence (agreement or resemblance) among brand positioning strategies of selected car brands are presented in Table V. These results reveal the presence of 59 percent congruence between experts' presumed positioning strategies and actual communicated strategies, while in 46 percent of the cases there is reflection of disagreement. On the other hand, the presence of agreement between actual communicated strategies and perceived strategies is 62 percent and 37 percent disagreement appears in the results. The "Visual Artistic" and "Basic Features" are clearly the most popular positioning strategies employed by three car brands except Figo. However, the ambiguity lies between communicated and perceived strategies of WagonR, Santro and Spark as "Brand Image" and "Dealer Network and Services" strategies are well perceived by target group but these are neither presumed by experts nor communicated in advertisements. This finding clearly highlights the tru stworthiness and reliability of these brands which is well accepted without any management efforts in this direction. So, it is hereby suggested to the marketers to employ these strategies to gain competitive advantage. Findings also screen out that all the communicated strategies are not perceived by the customers meaning hereby that these efforts are in vain and there is no return of such advertising expense.

In this study, the most important part that needs managers' attention or concern is the investigation of congruence among positioning activities. As the results depict, "CP' (communicated strategies do not reflect the presumptions/perceptions) is of foremost concern followed by "NE" (strategy is not employed) and "PWC" (strategies present in presumptions/perceptions despite or without communication). So, it calls the need for the managers to be more practical on ground and reconsiders the positioning activities to curtail these ambiguities. 


\section{Conclusion, Managerial Implications and Limitations}

Positioning is exercised by every company but the more important aspect is to evaluate the degree to which the desired position is accomplished. In the light of this, the present paper has identified the positioning strategies employed by four wellknown Indian brands in the passenger car segment and the presence of congruence in their positioning activities. The results reveal the presence of two most popular positioning strategies "Visual Artistic" and "Basic Features" in case of three brands however Figo clearly stands on "Cost and Finance". No doubt, the results of Figo are more alarming as customers perceive three other strategies which are not even presumed by experts. So, managers need to reassess the activities in this direction to fill the gap. In the cases, where brands are sharing the same positioning, it theoretically appears to be a strategic mistake as positioning is concerned with the point of difference in customer's mind. The reason may be that the difference among these cars is cosmetically created as these all relate to the middle class target segment and are in low price range. Despite of this, when the cosmetically created differences are measured on typology, the comprehensive strategy comes out to be "Visual Artistic" and "Basic Features" as these dimensions consists of 15 and 12 items respectively. This finding highlights the extent of the critical brand tactics in positioning of the brands.

As far as managerial implications are concerned, this study serves as an insight for marketing managers, brand managers and advertising executives involved with car brands. They may consider the identified positioning strategies in this study and may consult the suggestions to reassess their positioning activities. This study is perhaps the first to operationalize the concept of positioning in automobile industry. There are evidences from literature that managers face difficulties in the application of the positioning concept in absence of guidelines (Pollay, 1985; de Chernatony, 1994; Piercy, 1991, 2005). So, this study makes the managers available with the strategies and approaches for assessing the congruence among positioning activities followed by companies. Further, this research contributes in the positioning literature in general and also tests a newly developed customer derived positioning typology in automobile sector. Hence to some extent, it responds to the suggestions made by Hooley et. al (2001) for methods to assess brands' competitive positions and their implementation.

Like every research, this study too is not free from limitations. The use of convenience and snowball sampling, subjective as well as content analysis and disparity in dates of data collection of advertisements and low response rate are some of the drawbacks of 
this research. Moreover, this study is focused on a single automobile sector and specific car brands and hence these findings may not be generalized. Further, the interpretations may be influenced by writings of various authors cited in this study (e.g. Aaker \& Shansby, 1982; Kirk \& Miller, 1986; Johar \& Sirgy, 1989; Batraet al, 1996; Frankfort-Nachmias \& Nachmias, 1996 and Blank son, 2004), as this study is in line with these directions.

\section{References}

Aaker, D. A.,\& Shansby, J. (1982).Positioning your product. Business Horizons, 25, 56-62.

Alden, D. L., Steenkamp, J.B.E.M.,\& Batra, R. (1999). Brand positioning through advertising in Asia, North America, and Europe: The role of global consumer culture. Journal of Marketing, 63, 75-87.

Arnott, D. C. (1992).Bases of financial services positioning in the personal pension, life assurance and personal equity plan sectors. PhD thesis, Manchester Business School, University of Manchester, UK.

Batra, R., Myers, J. G.,\&Aaker, D. A. (1996). AdvertisingManagement. NJ: PrenticeHall.

Blankson, C., \&Kalafatis, S.P. (2004).The development and validation of a scale measuring consumer/customer-derived generic typology of positioning strategies. Journal of Marketing Management,20,5-43.

Blankson, C.,\&Kalafatis, S.P. (2007).Positioning strategies of international and multicultural-oriented service brands. Journal of Services Marketing,21(6), 435-450.

Blankson, C., Kalafatis, S.P., Coffie, S. \&Tsogas M. H. (2014). Comparisons of media types and congruence in positioning of service brands. Journal of Product and Brand Management, 23(3), 162-179.

Blankson, C., Ketron, S. \&Darmoe, J. (2017). Role of positioning in the retail banking industry of Sub-Saharan Africa. Journal of Bank Marketing, 35(4), 685-713.

Childers, T. L., Pride,W. M.,\& Ferrell,O. C. (1980).A reassessment of the effects of appeals on response to mail surveys. Journal of Marketing Research, 17,36570.

Chowdhury, P. P., \& Marketer, C. (2013). Key strategies and issues of positioning: A review of past studies. American Academic \& Scholarly Research Journal, 5 (1), 55-66. 
Cochran, W. G. (1950). The comparison of percentages on matched samples. Biometrika,37, 256-66.

Crawford, C.M. (1985). A new positioning typology. Journal of Product Innovation Management, 4, 243-53.

deChernatony, L. (1994).Developing a more effective brand positioning. The Journal of Brand Management, 1(6),373-9.

Diwan, S. P.,\&Bodla, B.S. (2011).Development of empirically based customerderived positioning typology in automobile industry. Journal of Strategic Marketing, 19 (6), 531-550.

Diwan, S. P., \&Bodla, B.S. (2014-15). Investigating the congruence among the positioning strategies of three Indian car brands. Journal of Brand Strategy, 3 (4), 373-386.

Dovel, G. P. (1990). Stake it out; positioning success, step by step. Business Marketing, July, 43-51.

Easingwood, C.J.,\& Mahajan, V. (1989). Positioning of financial services for competitive strategy. Journal of Product Innovation Management, 6, 207-19.

Fayvishenko D. (2018). Formation of brand positioning strategy. Baltic Journal of Economic Studies, 4 (2), 245-248.

Fay, M.,\& Currier, G. (1994).The rise and fall of the copy point: the changing information content of print advertisements from 1953-1988. European Journal of Marketing, 28(10), 10-31.

Fill, C. (1999).Marketing communications: Contexts, Contents and Strategies. Europe: Prentice-Hall.

Fletcher, A. D., \& Bowers, T. A. (1991).Fundamentals of Advertising Research. 4th ed. Wadsworth Publishing, Belmont, CA.

Frankfort-Nachmias, C., \& Nachmias, D. (1996). Research Methods in Social Sciences. London: Arnold-Hodder Group.

Hawes, J. M.,Crittender, V.J., \& Crittender, W.F. (1987). The effect of personalisation, source and offer on mail survey response rate and speed. ABER,18(2), 54-63.

Hooley, G. J.,\& Saunders, J.(1993).Competitive positioning: The key to market success. London: Prentice-Hall.

Hooley, G. J., Greenley, G., Fahy, J.,\&Cadogan, J. (2001). Market focused revenues, competitive positioning and firm performance. Journal of Marketing Management, 17 (5/6), 503-52.

Hornik, J. (1982).Impact of pre-call request form and gender interaction on response to a mail survey. Journal of Marketing Research, 19, 144-51. 
Hsu, T. S., \&Feldt, L.S. (1969).The effect of limitations on the number of criterion scores on the significance level of the F-test. American Educations Research Journal,6, 515-27.

Janiszewska, K., \&Insch, A. (2012). The strategic importance of brand positioning in the place brand concept: Elements, structure and application capabilities. Journal of International Studies, 5 (1), 9-19.

Jobber, D. (1989).An examination of the effects of questionnaire factors on response to an industrial mail survey. International Journal of Research in Marketing, 6,129-40.

Johar, J. S., \&Sirgy, M. J. (1989).Positioning models in marketing: toward a normative - integrated model. Journal of Business and Psychology,3(4), 475-85.

Jun, S. P., \& Park, D. H. (2017). Visualization of brand positioning based on consumer web search information using social network analysis. Internet Research, 27 (2), 381-407.

Kachersky, L. \&Carnevale, M. (2015). Effects of pronoun brand name perspective and positioning on brand attitude. Journal of Product and Brand Management, 24 (2), 157-164.

Kirk, J., \& Miller, M. L. (1986).Reliability and Validity in Qualitative Research. Qualitative Research Methods Series1, Newbury Park, CA: Sage Publications.

Kotler, P. (1988).Marketing Management: Analysis, Planning, Implementation, and control. NJ : Englewood Cliffs, Prentice-Hall Inc.

Lawler-Wilson \& Fenwick I. (1978). A product positioning model: Problems and possibilities. Journal of Marketing, 42(2), 13.]

Lee, J. L., Kim, Y. \& Won, J. (2018). Sports brand positioning: Positioning congruence and consumer perceptions towards brands. International Journal of Sports Marketing and Sponsorship, 19 (4), 450-471.

Malhotra N. K.,\& Dash, S. (2009). Marketing Research: An Applied Orientation. Pearson Prentice Hall.

Park, C. W., Jaworski, B. J.,\&MacLnnis, D. J. (1986). Strategic brand concept-image management. Journal of Marketing, 50, 135-145.

Park, J., Rajagopal, P., Dillon, W., Chaiy, S. \&DeSarbo, W. (2017). A new bayesian spatial model for brand positioning. Journal of Modelling in Management, 12 (3), 404-431.

Piercy, N.F. (1991). Market-Led Strategic Change: Making Marketing Happen in your Organization. London: Butterworth - Heinemann. 
Piercy, N. F. (2005).Market-Led strategic change: A Guide to Transforming the Process of going to Market. London: Elsevier Butterworth Heinemann.

Pollay, R. W. (1985).The subsidizing sizzle: Adescriptive history of print advertising, 1900-1980. Journal of Marketing,,50 135-45.

Ries, A., \& Trout, J. (1981).Positioning: The Battle for your Mind. New York: McGraw-Hill,

Ries, A., \& Trout, J. (1986).Positioning: The Battle for your Mind. New York: McGraw-Hill.

Rossiter, J. R., \& Percy, L. (1997). Advertising Communications and Promotion Management. New York: The McGraw-Hill Companies.

Seggev, E. (1982).Testing persuasion by strategic positioning. Journal of Advertising Research, 22(1), 37-42.

Shams, S. M. R. (2015). Stakeholders' perceptions and reputational antecedents: A review of stakeholder relationships, reputation and brand positioning. Journal of Advances in Management Research, 12 (3), 314-329.

Stern, B. L., \&Resnik, A. J. (1991).Information content in television advertising: a replication and extension. Journal of Advertising Research, 21(2), 36-46.

Wang, H. J. (2017). A brand-based perspective on differentiation of green brand positioning: A network analysis approach. Management Decision, 55 (7), 1460-1475.

\section{Websites}

W1: www.thehindubusinessline.in

W2: www.articlesbase.com

W3: www.unlawyer.net 
Table I: Positioning strategies of WagonR

\begin{tabular}{|c|c|c|c|c|c|}
\hline \multirow[t]{2}{*}{ Strategies } & \multirow{2}{*}{$\begin{array}{c}\begin{array}{c}\text { Presumed } \\
\text { strategies }\end{array} \\
\text { Experts' } \\
\text { views }\end{array}$} & \multicolumn{3}{|c|}{ Communicated strategies } & \multirow{2}{*}{$\begin{array}{c}\begin{array}{c}\text { Perceived } \\
\text { strategies }\end{array} \\
\text { Target } \\
\text { group's } \\
\text { perceptions }\end{array}$} \\
\hline & & $N P$ & $P L$ & $T V$ & \\
\hline Visual Artistic & $\mathrm{x}$ & & $\mathrm{x}$ & $\mathrm{x}$ & $\mathrm{x}$ \\
\hline Contemporary Features & & & $\mathrm{x}$ & $\mathrm{x}$ & \\
\hline Basic Features & $\mathrm{x}$ & & $\mathrm{x}$ & $\mathrm{x}$ & $\mathrm{x}$ \\
\hline Security Measures & & & $\mathrm{x}$ & & \\
\hline Brand Image & & & $\mathrm{x}$ & & $\mathrm{x}$ \\
\hline Dealer Network and Services & & & & & $\mathrm{x}$ \\
\hline Promotional Campaign & & $\mathrm{x}$ & & & \\
\hline Cost and Finance & & & & & $\mathrm{x}$ \\
\hline Results of ANOVA tests & & $\begin{array}{l}\text { F-ratio }= \\
71.448 \\
\text { d.f }=423 \\
\text { Sig. }= \\
0.000\end{array}$ & $\begin{array}{l}\text { F-ratio = } \\
7.837 \\
\text { d.f }=55 \\
\text { Sig. }= \\
0.000\end{array}$ & $\begin{array}{l}\text { F-ratio } \\
= \\
19.810 \\
\text { d.f }=39 \\
\text { Sig. }= \\
0.000\end{array}$ & $\begin{array}{l}\text { F-ratio }= \\
37.932 \\
\text { d.f }=495 \\
\text { Sig. }=0.000\end{array}$ \\
\hline
\end{tabular}

NP: Newspapers; PL: Pamphlets; MG: Magazines; TV: Television

Table II: Positioning strategies of Santro

\begin{tabular}{|c|c|c|c|c|c|}
\hline \multirow[t]{2}{*}{ Strategies } & \multirow{2}{*}{$\begin{array}{c}\text { Presumed } \\
\text { strategies } \\
\text { Experts' } \\
\text { views }\end{array}$} & \multicolumn{3}{|c|}{ Communicated strategies } & \multirow{2}{*}{$\begin{array}{c}\begin{array}{c}\text { Perceived } \\
\text { strategies }\end{array} \\
\text { Target } \\
\text { group's } \\
\text { perceptions }\end{array}$} \\
\hline & & $N P$ & $P L$ & $T V$ & \\
\hline Visual Artistic & $\mathrm{X}$ & & $\mathrm{X}$ & $\mathrm{X}$ & $\frac{1}{\mathrm{x}}$ \\
\hline \multicolumn{6}{|l|}{ Contemporary Features } \\
\hline Basic Features & & & $\mathrm{x}$ & $\mathrm{x}$ & $\mathrm{x}$ \\
\hline Security Measures & & & $\mathrm{x}$ & & $\mathrm{x}$ \\
\hline Brand Image & & & & & $\mathrm{x}$ \\
\hline Dealer Network and Ser & & & & & $\mathrm{x}$ \\
\hline Promotional Campaign & & $\mathrm{x}$ & $\mathrm{x}$ & & \\
\hline Cost and Finance & & $\mathrm{x}$ & $\mathrm{x}$ & & \\
\hline Results of ANOVA tests & & $\begin{array}{l}\text { F-ratio }= \\
13.348 \\
\text { d.f }=119 \\
\text { Sig. }=0.000\end{array}$ & $\begin{array}{l}\text { F-ratio }= \\
6.957 \\
\text { d.f }=71 \\
\text { Sig. }=0.000\end{array}$ & $\begin{array}{l}\text { F-ratio }= \\
11.444 \\
\text { d.f }=63 \\
\text { Sig. }=0.000\end{array}$ & $\begin{array}{l}\text { F-ratio }= \\
16.115 \\
\text { d.f }=447 \\
\text { Sig. }=0.000 \\
\end{array}$ \\
\hline
\end{tabular}


Table III: Positioning strategies of Spark

\begin{tabular}{|c|c|c|c|c|}
\hline \multirow[t]{2}{*}{ Strategies } & \multirow{2}{*}{$\begin{array}{c}\begin{array}{c}\text { Presumed } \\
\text { strategies }\end{array} \\
\text { Experts' } \\
\text { views }\end{array}$} & \multicolumn{2}{|c|}{ Communicated strategies } & \multirow{2}{*}{$\begin{array}{c}\begin{array}{c}\text { Perceived } \\
\text { strategies }\end{array} \\
\text { Target group 's } \\
\text { perceptions }\end{array}$} \\
\hline & & $N P$ & $T V$ & \\
\hline Visual Artistic & $\mathrm{x}$ & & $\mathrm{x}$ & $\mathrm{x}$ \\
\hline \multicolumn{5}{|l|}{ Contemporary Features } \\
\hline Basic Features & $\mathrm{x}$ & $\mathrm{x}$ & $\mathrm{x}$ & $\mathrm{x}$ \\
\hline \multicolumn{5}{|l|}{ Security Measures } \\
\hline Brand Image & & & & $\mathrm{x}$ \\
\hline \multicolumn{5}{|c|}{ Dealer Network and Services } \\
\hline Promotional Campaign & & $\mathrm{x}$ & & \\
\hline \multirow[t]{2}{*}{ Cost and Finance } & & $\mathrm{x}$ & & $\mathrm{x}$ \\
\hline & & $\begin{array}{l}\text { F-ratio }= \\
28.174 \\
\text { d.f }=151 \\
\text { Sig. }=0.000\end{array}$ & $\begin{array}{l}\text { F-ratio = } \\
11.286 \\
\text { d.f }=23 \\
\text { Sig. }= \\
0.000\end{array}$ & $\begin{array}{l}\text { F-ratio = } \\
15.440 \\
\text { d.f }=287 \\
\text { Sig. } \\
=0.000\end{array}$ \\
\hline
\end{tabular}

Table IV: Positioning strategies of Ford Figo

\begin{tabular}{|c|c|c|c|c|c|c|}
\hline \multirow[t]{2}{*}{ Strategies } & \multirow{2}{*}{$\begin{array}{c}\text { Presumed } \\
\text { strategies } \\
\text { Experts' } \\
\text { views }\end{array}$} & \multicolumn{4}{|c|}{ Communicated strategies } & \multirow{2}{*}{$\begin{array}{c}\begin{array}{c}\text { Perceived } \\
\text { strategies }\end{array} \\
\text { Target } \\
\text { group's } \\
\text { perceptions }\end{array}$} \\
\hline & & $N P$ & $P L$ & $M G$ & $T V$ & \\
\hline Visual Artistic & & $\mathrm{x}$ & $\mathrm{x}$ & $\mathrm{x}$ & $\mathrm{x}$ & $\mathrm{x}$ \\
\hline \multicolumn{7}{|l|}{ Contemporary Features } \\
\hline Basic Features & & $\mathrm{x}$ & $\mathrm{x}$ & $\mathrm{x}$ & $\mathrm{x}$ & $\mathrm{x}$ \\
\hline Security Measures & & & $\mathrm{x}$ & & & \\
\hline Brand Image & & $\mathrm{x}$ & $\mathrm{x}$ & $\mathrm{x}$ & $\mathrm{x}$ & $\mathrm{x}$ \\
\hline \multicolumn{7}{|l|}{$\begin{array}{l}\text { Dealer Network and } \\
\text { Services } \\
\text { Promotional Campaign }\end{array}$} \\
\hline Cost and Finance & $\mathrm{x}$ & $\mathrm{x}$ & $\mathrm{x}$ & & & $\mathrm{x}$ \\
\hline Results of ANOVA tests & & $\begin{array}{l}\text { F-ratio = } \\
24.659 \\
\text { d.f }=119 \\
\text { Sig. }= \\
0.000\end{array}$ & $\begin{array}{l}\text { F-ratio = } \\
6.195 \\
\text { d.f }=31 \\
\text { Sig. }= \\
0.000\end{array}$ & $\begin{array}{l}\text { F-ratio } \\
=9.245 \\
\text { d.f }=31 \\
\text { Sig. } \\
=0.000\end{array}$ & $\begin{array}{l}\text { F-ratio } \\
=16.00 \\
\text { d.f }=23 \\
\text { Sig. }= \\
0.000\end{array}$ & $\begin{array}{l}\text { F-ratio }= \\
109.824 \\
\text { d.f }=311 \\
\text { Sig. }=0.000\end{array}$ \\
\hline
\end{tabular}


TableV: Congruence in positioning activities/strategies of selected car brands.

\begin{tabular}{|c|c|c|c|c|c|c|c|c|}
\hline \multirow[t]{2}{*}{ Strategies } & \multicolumn{4}{|c|}{$\begin{array}{l}\text { Presumed Vs. Actual } \\
\text { communicated strategies }\end{array}$} & \multicolumn{4}{|c|}{$\begin{array}{l}\text { Actual communicated strategies } \\
\text { Vs. Perceived strategies }\end{array}$} \\
\hline & $\begin{array}{l}\text { Wagon } \\
\mathrm{R}\end{array}$ & Santro & Spark & Figo & $\begin{array}{c}\text { Wagon } \\
\mathrm{R}\end{array}$ & Santro & Spark & Figo \\
\hline Visual Artistic & $\mathrm{E}$ & $\mathrm{E}$ & $\mathrm{E}$ & $\mathrm{CP}$ & $\mathrm{E}$ & $\mathrm{E}$ & $\mathrm{E}$ & $\mathrm{E}$ \\
\hline Contemporary Features & $\mathrm{CP}$ & $\mathrm{NE}$ & NE & NE & $\mathrm{CP}$ & $\mathrm{NE}$ & NE & NE \\
\hline Basic Features & $\mathrm{E}$ & $\mathrm{E}$ & E & $\mathrm{CP}$ & $\mathrm{E}$ & $\mathrm{E}$ & $\mathrm{E}$ & $\mathrm{E}$ \\
\hline Security Measures & $\mathrm{CP}$ & $\mathrm{CP}$ & $\mathrm{NE}$ & $\mathrm{CP}$ & $\mathrm{CP}$ & $\mathrm{E}$ & NE & $\mathrm{CP}$ \\
\hline Brand Image & $\mathrm{CP}$ & NE & $\mathrm{NE}$ & $\mathrm{CP}$ & $\mathrm{E}$ & PWC & PWC & E \\
\hline $\begin{array}{l}\text { Dealer Network and } \\
\text { Services }\end{array}$ & NE & $\mathrm{NE}$ & $\mathrm{NE}$ & NE & PWC & PWC & NE & NE \\
\hline Promotional Campaign & $\mathrm{CP}$ & $\mathrm{CP}$ & $\mathrm{CP}$ & NE & $\mathrm{CP}$ & $\mathrm{CP}$ & $\mathrm{CP}$ & NE \\
\hline Cost and Finance & NE & $\mathrm{CP}$ & $\mathrm{CP}$ & $\mathrm{E}$ & PWC & $\mathrm{CP}$ & E & $\mathrm{E}$ \\
\hline \multicolumn{4}{|c|}{$\begin{array}{l}{ }^{1} \mathrm{NE}=12 / 32(37 \text { percent }) \\
{ }^{2} \mathrm{E}=7 / 32(22 \text { percent }) \\
{ }^{3} \mathrm{CP}=13 / 32(41 \text { percent }) \\
{ }^{4} \mathrm{PWC}=0 \\
\text { Congruence/ link }(\mathrm{E}+\mathrm{NE})=19 / 32(59 \text { percent }) \\
\text { No congruence/ no link }(\mathrm{CP}+\mathrm{PWC})= \\
\qquad 13 / 32(41 \text { percent })\end{array}$} & $\begin{array}{l}{ }^{1} \mathrm{NE}= \\
{ }^{2} \mathrm{E}=1 \\
{ }^{3} \mathrm{CP}= \\
{ }^{4} \mathrm{PWC} \\
\text { Cong } \\
(62.51 \\
\text { No cc }\end{array}$ & $\begin{array}{l}7 / 32(22 \\
3 / 32(41 \\
7 / 32(22 \\
=5 / 32 \\
\text { uence/ } \\
\text { ercent) } \\
\text { ngruence } \\
\qquad\end{array}$ & $\begin{array}{l}\text { percent) } \\
\text { ercent) } \\
\text { ercent) } \\
5 \text { percen } \\
k(E+N \\
\text { no link } \\
12 / 32 \\
5 \text { perce }\end{array}$ & $\begin{array}{l}=20 / 32 \\
P+P W C\end{array}$ & \\
\hline \multicolumn{9}{|c|}{$\begin{array}{l}{ }^{1} \mathrm{NE} \text { : Strategy is not employed, }{ }^{2} \mathrm{E}: \text { Strategy is employed, }{ }^{3} \mathrm{CP} \text { : Communicated strategies do not } \\
\text { reflect the presumptions/perceptions, }{ }^{4} \mathrm{PWC} \text { : Strategies present in presumptions/ perceptions } \\
\text { despite or without communication }\end{array}$} \\
\hline
\end{tabular}

\section{Appendix 1: Positioning Typology}

\begin{tabular}{ll}
\hline Strategy Name & \multicolumn{1}{c}{ Statements } \\
\hline Visual Artistic & $\begin{array}{l}\text { Exterior styling, Fashionable, Express personality, Styling, } \\
\text { Superior, Makes statement, Elegant design, Status, } \\
\text { Modern, Interior styling, Posh, Size, Color selection, } \\
\text { Aesthetics and Sporty }\end{array}$ \\
& $\begin{array}{l}\text { High tech, Airbags, Extra features, Eco-friendly, Baby seat } \\
\text { and Silence at high speed }\end{array}$ \\
Contemporary &
\end{tabular}


Basic Features

Security Measures

Brand Image

Dealer Network and Services

Promotional

Campaign

Cost and Finance
Safety, Pickup, Maintenance cost, Value for money, Durability, Convenience, Passenger comfort, Features, Driving comfort, Handling, Good fit and Fuel efficiency

Security system, Power brakes, Child lock and Remote lock

Brand name, Reputation, Name of company, Popularity, Leader in market, Reliability and Image consistency

After sale services, Dealer network and Spare parts availability

Trustworthy ads, Promotional activities and Celebrity in advertisements

Financing period, Interest for finance and Price

Source: Diwan and Bodla, 2011

\section{Appendix 2}

In this section, the results of ANOVA tests on marketing communications and target group perceptions regarding positioning strategies of three car brands are presented.

\section{Positioning strategies identified from communications of Maruti -WagonR}

\begin{tabular}{|c|c|c|c|c|c|c|c|}
\hline \multirow[t]{2}{*}{ Strategies } & \multicolumn{2}{|c|}{ Newspapers } & \multicolumn{2}{|c|}{ Pamphlets } & \multicolumn{2}{|c|}{ T.V. } & \multirow{2}{*}{$\begin{array}{c}\text { Overall } \\
\text { No. }\end{array}$} \\
\hline & No. & $\%$ & No. & $\%$ & No. & $\%$ & \\
\hline Visual Artistic & 4 & 7 & 7 & 100 & 5 & 100 & 16 \\
\hline Contemporary Features & 1 & 2 & 2 & 29 & 0 & 0 & 3 \\
\hline Basic Features & 6 & 11 & 4 & 57 & 3 & 60 & 13 \\
\hline Security Measures & 2 & 4 & 5 & 71 & 0 & 0 & 7 \\
\hline Brand Image & 4 & 7 & 2 & 29 & 0 & 0 & 6 \\
\hline $\begin{array}{l}\text { Dealer Network and } \\
\text { Services }\end{array}$ & 1 & 2 & 0 & 0 & 0 & 0 & 1 \\
\hline Promotional Campaign & 50 & 94 & 0 & 0 & 0 & 0 & 50 \\
\hline Cost and Finance & 23 & 43 & 0 & 0 & 0 & 0 & 23 \\
\hline $\begin{array}{l}\text { Number of ads examined } \\
\text { Results of ANOVA tests }\end{array}$ & $\begin{array}{l}53 \\
\text { F-rat } \\
71.4 \\
\text { d.f }= \\
\text { Sig. }\end{array}$ & 81 & $\begin{array}{l}7 \\
\text { F-r } \\
7.8 \\
\text { d.f } \\
\text { Sig }\end{array}$ & 5.000 & $\begin{array}{l}5 \\
\text { F-r } \\
19 . \\
\text { d.f } \\
\text { Sig }\end{array}$ & & \begin{tabular}{l}
\multicolumn{1}{c}{65} \\
F-ratio = \\
31.083 \\
d.f $=519$ \\
Sig.= \\
0.000
\end{tabular} \\
\hline
\end{tabular}


Positioning strategies identified from communications of Hyundai - Santro

\begin{tabular}{|c|c|c|c|c|c|c|c|c|}
\hline \multirow[t]{2}{*}{ Strategies } & \multicolumn{2}{|c|}{ Newspapers } & \multicolumn{2}{|c|}{ Pamphlets } & \multicolumn{2}{|c|}{ T.V. } & \multicolumn{2}{|c|}{ Overall } \\
\hline & No. & $\%$ & No. & $\%$ & No. & $\%$ & No. & $\%$ \\
\hline Visual Artistic & 0 & 0 & 6 & 67 & 7 & 87 & 14 & 44 \\
\hline Contemporary Features & 0 & 0 & 0 & 0 & 0 & 0 & 0 & 0 \\
\hline Basic Features & 2 & 13 & 5 & 56 & 5 & 62 & 13 & 41 \\
\hline Security Measures & 2 & 13 & 1 & 11 & 0 & 0 & 3 & 9 \\
\hline Brand Image & 5 & 33 & 0 & 0 & 1 & 12 & 6 & 19 \\
\hline $\begin{array}{l}\text { Dealer Network and } \\
\text { Services }\end{array}$ & 0 & 0 & 0 & 0 & 0 & 0 & 0 & 0 \\
\hline Promotional Campaign & 13 & 87 & 7 & 78 & 0 & 0 & 21 & 66 \\
\hline Cost and Finance & 8 & 53 & 4 & 44 & 1 & 12 & 13 & 41 \\
\hline Number of ads examined & & 47 & 9 & 28 & 8 & 25 & 32 & \\
\hline Results of ANOVA tests & \multicolumn{2}{|c|}{$\begin{array}{c}\text { F-ratio }= \\
13.348 \\
\text { d.f }=119 \\
\text { Sig. }=0.000\end{array}$} & \multicolumn{2}{|c|}{$\begin{array}{l}\text { F-ratio }= \\
6.957 \\
\text { d.f }=71 \\
\text { Sig. }=0.000\end{array}$} & \multicolumn{2}{|c|}{$\begin{array}{l}\text { F-ratio }= \\
11.444 \\
\text { d.f }=63 \\
\text { Sig. }=0.000\end{array}$} & \multicolumn{2}{|c|}{$\begin{array}{l}\text { F-ratio = } \\
10.651 \\
\text { d.f }=255 \\
\text { Sig. }=0.00\end{array}$} \\
\hline
\end{tabular}

\section{Positioning strategies identified from communications of Chevrolet - Spark}

\begin{tabular}{lcccccc}
\hline Strategies & \multicolumn{2}{c}{ Newspapers } & \multicolumn{2}{c}{ T.V. } & \multicolumn{2}{c}{ Overall } \\
\cline { 2 - 7 } & No. & $\%$ & No. & $\%$ & No. & $\%$ \\
\hline Visual Artistic & 1 & 5 & 3 & 100 & 4 & 18 \\
Contemporary Features & 0 & 0 & 0 & 0 & 0 & 0 \\
Basic Features & 12 & 63 & 2 & 67 & 14 & 64 \\
Security Measures & 0 & 0 & 0 & 0 & 0 & 0 \\
Brand Image & 2 & 10 & 0 & 0 & 2 & 9 \\
Dealer Network and Services & 0 & 0 & 0 & 0 & 0 & 0 \\
Promotional Campaign & 14 & 74 & 0 & 0 & 14 & 64 \\
Cost and Finance & 16 & 84 & 0 & 0 & 16 & 73 \\
\hline $\begin{array}{l}\text { No. of ads examined } \\
\text { Results of ANOVA tests }\end{array}$ & $\begin{array}{l}19 \\
\text { F-ratio }=28.174\end{array}$ & $\begin{array}{l}\text { F-ratio }=11.286 \\
\text { d.f }=151\end{array}$ & $\begin{array}{l}\text {.f }=23 \\
\text { Sig. }=0.000\end{array}$ & $\begin{array}{l}\text { F-ratio }=19.750 \\
\text { Sig. }=0.000\end{array}$ \\
\hline
\end{tabular}


Positioning strategies identified from communications of Ford - Figo

\begin{tabular}{|c|c|c|c|c|c|c|c|c|c|c|}
\hline \multirow[t]{2}{*}{ Strategies } & \multicolumn{2}{|c|}{ Newspapers } & \multicolumn{2}{|c|}{ Pamphlets } & \multicolumn{2}{|c|}{ Magazines } & \multicolumn{2}{|c|}{ T.V. } & \multicolumn{2}{|c|}{ Overall } \\
\hline & No. & $\%$ & No. & $\%$ & No. & $\%$ & No. & $\%$ & No. & $\%$ \\
\hline Visual Artistic & 12 & 80 & 4 & 100 & 3 & 75 & 3 & 100 & 22 & 85 \\
\hline Contemporary Features & 1 & 7 & 0 & 0 & 0 & 0 & 0 & 0 & 1 & 4 \\
\hline Basic Features & 14 & 93 & 4 & 100 & 4 & 100 & 3 & 100 & 25 & 96 \\
\hline Security Measures & 0 & 0 & 2 & 50 & 0 & 0 & 0 & 0 & 2 & 8 \\
\hline Brand Image & 8 & 53 & 2 & 50 & 2 & 50 & 2 & 67 & 14 & 54 \\
\hline $\begin{array}{l}\text { Dealer Network and } \\
\text { Services }\end{array}$ & 0 & 0 & 0 & 0 & 0 & 0 & 0 & 0 & 0 & 0 \\
\hline Promotional Campaign & 1 & 7 & 0 & 0 & 0 & 0 & 0 & 0 & 1 & 4 \\
\hline Cost and Finance & 12 & 80 & 1 & 25 & 0 & 0 & 0 & 0 & 13 & 50 \\
\hline $\begin{array}{l}\text { No. of ads examined } \\
\text { Results of ANOVA tests }\end{array}$ & $\begin{array}{l}15 \\
\text { F-ra } \\
24.6 \\
\text { d.f }= \\
\text { Sig. }\end{array}$ & $\begin{array}{l}9 \\
000\end{array}$ & $\begin{array}{l}4 \\
\text { F-rr } \\
6.1 \\
\text { d.f } \\
\text { Sig } \\
0.0\end{array}$ & $\begin{array}{l}15 \\
0= \\
31\end{array}$ & $\begin{array}{c}4 \\
\text { F-ro } \\
9.2 \\
\text { d.f } \\
\text { Sig } \\
0.0\end{array}$ & $\begin{array}{l}15 \\
o= \\
31\end{array}$ & $\begin{array}{c}3 \\
\text { F-rr } \\
16 . \\
\text { d.f } \\
\text { Sig. } \\
0.0\end{array}$ & $\begin{array}{l}11 \\
0= \\
23\end{array}$ & $\begin{array}{l}\text { F-r } \\
37 . \\
\text { d.f } \\
\text { Sig }\end{array}$ & $\begin{array}{l}= \\
307 \\
0.000\end{array}$ \\
\hline
\end{tabular}

